\begin{tabular}{c} 
PEDIOMATERNAL \\
NURSING JOURNAL \\
Vol. 5, No. 1, Maret 2019 \\
Jediomaternal \\
Journal Homepage: https://e-journal.unair.ac.id/PMNJ// \\
\hline
\end{tabular}

Original Research

\title{
Analisis Perilaku Pencegahan Keputihan pada Remaja Putri berdasarkan Teori Health Promotion Model (HPM)
}

\section{(The Prevention of vaginal discharge Behavior Analysis on Young Women based on the Health Promotion Model (HPM)}

\author{
Frida Rachmadianti, Ni Ketut Alit Armini, dan Aria Aulia Nastiti \\ Fakultas Keperawatan, Universitas Airlangga, Surabaya, Jawa Timur, Indonesia
}

\author{
ARTICLE HISTORY \\ Received: April 02, 2019 \\ Accepted: May 29, 2019

\section{KEYWORDS} \\ adolescence; vaginal discharge; \\ behavior; health promotion \\ model

\section{CORRESPONDING AUTHOR} \\ Frida Rachmadianti \\ frida.rachmadianti \\ 2017@fkp.unair.ac.id \\ Fakultas Keperawatan, \\ Universitas Airlangga, Surabaya, \\ Jawa Timur, Indonesia
}

Cite this as:

\begin{abstract}
Introduction: The behavior of prevention of vaginal discharge in adolescents is still a health problem that needs attention. Vaginal discharge will have a harmful impact on adolescents, that is infection, pelvic inflammatory disease, infertility and malignancy (tumors and cancer). The HPM theory emphasizes the active role of someone in regulating the behavior of preventing an illness. The purpose of this study was to analyze the factors associated with the behavior of prevention of vaginal discharge in young women based on the Health Promotion Model (HPM) theory.

Methods: The design of this study was analytical descriptive with a cross-sectional approach. Sampling uses simple random sampling technique. Large sample of 140 female students. Independent variables are self motivation, perceived benefits, interpersonal influences, and action commitment and the dependent variable is whiteness prevention behavior. The instrument used was a questionnaire. Analysis using logistic regression statistical test with $\alpha \leq 0.05$.

Results: Factors related to whiteness prevention behavior were self motivation ( $p=$ $0,000)$, perceived benefits $(p=0,000)$, interpersonal influences $(p=0,020)$, and unrelated actions commitment $(\mathrm{p}=0,102)$.

Conclusion: The majority of female students have good behavior, self-motivation, perceived benefits, high interpersonal influences will improve vaginal prevention behavior. However, the commitment of actions does not contribute to the prevention behavior of vaginal discharge.
\end{abstract}

Rachmadianti, F., Armini, N. K. A., \& Nastiti, A. (2019). Analisis Perilaku Pencegahan Keputihan pada Remaja Putri berdasarkan Teori Health Promotion Model (HPM). Pediomaternal Nurs. J., 5(1), 137-144.

\section{PENDAHULUAN}

Remaja merupakan masa transisi dari masa kanakkanak sampai dewasa yang mengalami perubahan secara dramatis baik dari fisik maupun psikologis (1). Remaja mengalami kematangan organ reproduksi yang ditandai dengan menstruasi (2) . Semakin dini usia kematangan organ reproduksi maka semakin panjang periode risiko kesehatan reproduksinya (2). Masalah kesehatan reproduksi menjadi fokus perhatian yang utama pada remaja. Keputihan patologis sering terjadi pada remaja namun tidak disadari atau diperhatikan. Keputihan sering dianggap tidak serius atau sebagai suatu hal yang normal namun pada kenyataannya keputihan dapat dikatakan normal (fisiologis) dan dikatakan tidak normal (patologis) (3). Penelitian (4) faktor yang dapat mempengaruhi kejadian keputihan patologis pada remaja tersebut yaitu pengetahuan vulva hygiene, gerakan membersihkan vagina, penggunaan celana dalam ketat dan penggunaan toilet umum. Teori Health Promotion Model menekankan pada peran aktif seseorang dalam mengatur perilaku sehatnya yang menjelaskan mengenai promosi kesehatan yang bertujuan sebagai pencegahan suatu penyakit (5). 
Menurut (6) berdasarkan data statistik di Indonesia tahun 2008, dari 43,3 juta jiwa remaja berusia 15-24 tahun berperilaku tidak sehat, seperti penggunaan cairan pembersih vagina, celana ketat, personal hygiene dan pemakaian panty liner (7) yang merupakan salah satu penyebab terjadinya keputihan. Survei (8) menunjukkan 75\% perempuan menderita keputihan minimal sekali seumur hidup, $45 \%$ bisa mengalami keputihan sebanyak dua kali atau lebih. Berdasarkan studi pendahuluan pada siswi SMA Hang Tuah 2 Sidoarjo kelas XII yang berjumlah 15 siswi tentang perilaku pencegahan keputihan menunjukkan bahwa $47 \%$ melakukan pola hidup sehat (olahraga, diet seimbang, menghindari stress), 66\% memakai pakaian dalam berbahan katun, $80 \%$ mengganti pakaian dalam minimal $2 \mathrm{x}$ sehari, $73 \%$ menggunakan celana ketat, $60 \%$ memakai panty liner, $73 \%$ melakukan cara membasuh vagina yang salah, 33\% menggunakan sabun pembersih vagina, 66\% menggunakan tisu dengan pewangi untuk mengeringkan daerah kewanitaan, $73 \%$ menghindari meminjam barang yang memudahkan penularan (celana dalam, handuk), dan $66 \%$ menghindari konsumsi jamujamuan.

Bagi remaja perempuan penting sekali sejak dini merawat genetalia secara tepat untuk mengurangi resiko keputihan. Keputihan akan membawa dampak yang berbahaya bagi remaja yaitu infeksi, penyakit radang panggul, infertilitas, dan gangguan psikologis (9). Faktor yang berhubungan dengan perilaku pencegahan keputihan pada remaja meliputi beberapa hal yaitu penggunaan cairan pembersih vagina, celana ketat, personal hygiene dan pemakaian panty liner (7). Penggunaan cairan pembersih vagina akan mengganggu $\mathrm{pH}$ dan bakteri baik sehingga bakteri jahat berkembang pesat dan vagina akan rentan terjadi keputihan (10). Pemakaian celana yang terlalu ketat juga dapat menghambat aliran udara sehingga keringat sulit diserap dan bakteri mudah berkembang yang akan menyebabkan keputihan (11). Personal hygiene yang kurang pada area genetalia menyebabkan kuman, parasit, dan virus berkembang dengan pesat di daerah sekitar kemaluan wanita (12). Selain itu pemakaian panty liner dapat meningkatkan populasi Eubacterium species di vagina dan menurunkan jumlah Lactobacillus species di vagina sebagai flora normal sehingga dapat meningkatkan risiko terjadinya keputihan (13).

Teori Health Promotion Model (HPM) menurut (5) menjelaskan bahwa untuk menggambarkan hubungan antara manusia dengan lingkungan fisik dan interpersonalnya dalam berbagai dimensi. Pendekatan teori ini berfokus pada kemampuan individu untuk mempertahankan kondisi kesehatannya dengan keyakinan bahwa lebih baik melakukan tindakan pencegahan penyakit yang mengarah kepada perbaikan kondisi yang dimilikinya (5). Teori health promotion model telah diterapkan sebagai upaya pencegahan dan peningkatan kesehatan dalam berbagai aspek kehidupan seperti nutrisi, aktivitas, dan gaya hidup sehat yang ditujukan pada pencapaian hasil kesehatan positif untuk klien dan berpengaruh terhadap kualitas hidup yang lebih baik pada semua tingkat perkembangan. Perilaku pencegahan keputihan menjadi salah satu prioritas untuk meningkatkan kesehatan reproduksi pada remaja secara optimal. Tujuan penelitian ini adalah menganalisis faktor yang berhubungan dengan perilaku pencegahan keputihan pada remaja putri berdasarkan teori Health Promotion Model (HPM).

\section{METODE}

\subsection{Desain}

Desain penelitian ini menggunakan desain penelitian deskriptif analitik dengan pendekatan cross sectional yaitu peneliti mengukur/ mengobservasi data variabel independen dan dependen hanya sekali pada satu waktu.

\subsection{Populasi, sampel, dan sampling}

Sampel didapatkan dengan cara peneliti memilih siswi kelas XI SMA Hang Tuah 2 Sidoarjo yang sesuai dengan kriteria inklusi yaitu remaja putri berusia 1518 tahun dan telah mendapatkan menstruasi dari total populasi sebanyak 216 orang. Kemudian dilakukan teknik simple random sampling yaitu siswi kelas XI SMA Hang Tuah 2 Sidoarjo dipilih secara acak dengan menggunakan lotre yang di dalamnya terdapat nama siswi yang sudah memenuhi kriteria inklusi yaitu remaja putri berusia 15-18 tahun dan telah mendapatkan menstruasi yang diambil sesuai dengan besar sampel sebanyak 140 orang.

\subsection{Variabel}

Variabel independen dalam penelitian ini berasal dari komponen Teori Health Promotion Model (HPM) yaitu: Motivasi diri, manfaat yang dirasakan (perceived benefits of action), pengaruh interpersonal, komitmen tindakan. Variabel dependen pada penelitian ini adalah perilaku pencegahan keputihan.

\subsection{Instrumen}

Kuesioner perilaku pencegahan keputihan menggunakan modifikasi kuesioner (14) yang telah dilakukan uji validitas dan dinyatakan valid dengan $\alpha$ $\leq 0,05$ dan reliabel dengan nilai (r) 0, 855. Instrumen ini menggunakan kuesioner skala likert berjumlah 10 pernyataan, dengan 4 pilihan jawaban yaitu tidak pernah $(\mathrm{TP})=1$, kadang-kadang $(\mathrm{KK})=2$, sering $(\mathrm{SR})=$ 3 , selalu $(S L)=4$. Penilaian kategori skor total perilaku pencegahan yaitu apabila skor $\geq$ mean maka perilaku pencegahan keputihan dikategorikan baik, sedangkan jika nilai skor < mean maka perilaku pencegahan dikategorikan buruk.

Kuesioner motivasi diri menggunakan modifikasi kuesioner (15) yang telah dilakukan uji validitas dan dinyatakan valid dengan $\alpha \leq 0,05$ dan reliabel dengan nilai (r) 0,745. Instrumen ini menggunakan kuesioner skala likert berjumlah 6 pernyataan, dengan 4 pilihan jawaban yaitu sangat tidak setuju $(\mathrm{STS})=1$, tidak setuju $(\mathrm{TS})=2$, setuju $(\mathrm{S})=$ 
3, sangat setuju $(\mathrm{SS})=4$. Penilaian kategori skor total motivasi diri yaitu apabila skor $\geq$ mean maka motivasi diri dikategorikan tinggi, sedangkan jika nilai skor $<$ mean maka motivasi diri dikategorikan rendah.

Kuesioner manfaat yang dirasakan (perceived benefits) menggunakan kuesioner yang dibuat oleh peneliti sendiri namun tetap mengacu pada Teori Health Promotion Model (HPM) yang telah dilakukan uji validitas dan dinyatakan valid dengan $\alpha \leq 0,05$ dan reliabel dengan nilai (r) 0,664. Instrumen ini menggunakan kuesioner skala likert berjumlah 5 pernyataan, dengan 4 pilihan jawaban yaitu sangat tidak setuju $(\mathrm{STS})=1$, tidak setuju $(\mathrm{TS})=2$, setuju $(\mathrm{S})=$ 3 , sangat setuju $(S S)=4$. Penilaian kategori skor manfaat yang dirasakan (perceived benefits) yaitu apabila skor $\geq$ mean dikategorikan tinggi, sedangkan jika nilai skor < mean dikategorikan rendah.

Kuesioner pengaruh interpersonal menggunakan modifikasi kuesioner (16) yang telah dilakukan uji validitas dan dinyatakan valid dengan $\alpha$ $\leq 0,05$ dan reliabel dengan nilai $(r) 0,773$. Instrumen ini menggunakan kuesioner skala likert berjumlah 6 pernyataan, dengan 4 pilihan jawaban yaitu tidak pernah $(\mathrm{TP})=1$, kadang-kadang $(\mathrm{KK})=2$, sering $(\mathrm{SR})=$ 3 , selalu $(S L)=4$. Penilaian kategori skor total pengaruh interpersonal yaitu apabila skor $\geq$ mean maka pengaruh interpersonal dikategorikan tinggi, sedangkan jika nilai skor < mean maka dikategorikan rendah.

Kuesioner komitmen tindakan menggunakan modifikasi kuesioner (16) yang telah dilakukan uji validitas dan dinyatakan valid dengan $\alpha \leq 0,05$ dan reliabel dengan nilai (r) 0, 875. Instrumen ini menggunakan kuesioner skala Guttman berjumlah 8 pernyataan, dengan 2 pilihan jawaban yaitu $\mathrm{Ya}=1$, Tidak $=0$. Penilaian kategori skor total komitmen tindakan yaitu apabila skor $\geq$ mean maka komitmen tindakan dikategorikan kuat, sedangkan jika nilai skor < mean maka dikategorikan lemah.

\subsection{Prosedur}

Penelitian dilaksanakan di SMA Hang Tuah 2 Sidoarjo. Peneliti masuk pada setiap kelas XI untuk menentukan responden penelitian yang sesuai dengan kriteria inklusi yaitu remaja putri berusia 1518 tahun dan telah mendapatkan menstruasi. Setelah itu peneliti melakukan lotre secara acak nama-nama siswi yang memenuhi kriteria sebagai responden sebanyak 140 orang sesuai dengan besar sampel. Setelah mendapatkan sampel, peneliti dan guru BK masuk ke setiap kelas siswi yang menjadi calon responden penelitian. Kemudian peneliti menjelaskan mengenai penelitian dan mengajukan inform concent kepada responden. Pengisian inform concent dilakukan pendampingan oleh guru BK sebagai wali responden dan saksi dalam penelitian ini. Setelah meminta persetujuan untuk menjadi responden penelitian (informed consent), peneliti mendampingi responden selama pengisian kuesioner untuk membantu responden bila mengalami kesulitan dalam pengisian kuesioner. Kuesioner yang telah diisi kemudian diberikan kembali kepada peneliti. Penelitian ini dilakukan dalam satu hari yang berlangsung pukul 08.00-11.00 WIB. Proses pengambilan data berlangsung dengan baik dan peneliti tidak mengalami masalah atau hambatan dalam penelitian.

\subsection{Analisis}

Penelitian ini dilakukan analisa data dengan uji Regresi Logistik dengan signifikasi $\alpha \leq 0,05$.

\subsection{Ethical Clearance}

Penelitian ini telah dinyatakan lolos kaji etik dan mendapatkan sertifikat Ethical Approval dengan No. 1234-KEPK yang dikeluarkan oleh Komite Etik Penelitian Kesehatan Fakultas Keperawatan Universitas Airlangga pada tanggal 21 Desember 2018.

\section{Hasil}

Karakteristik menurut usia responden bahwa mayoritas usia responden adalah 16 tahun sebanyak 113 siswi $(80,7 \%)$, usia menarch pada siswi mayoritas menarche normal sebanyak 137 siswi $(97,9 \%)$, responden mayoritas merupakan anak pertama yaitu sebanyak 70 siswi (50\%) dan memiliki saudara perempuan sebanyak 71 siswi $(50,7 \%)$, responden bertempat tinggal di rumah orang tua dengan jumlah sebanyak 140 siswi (100\%), penghasilan orangtua responden mayoritas $>3.500 .000$ yaitu sebanyak 83 siswi $(59,3 \%)$ [Tabel 1].

Responden yang mengetahui tentang keputihan yaitu 118 siswi $(84,3 \%)$ dan yang mengetahui tentang perilaku pencegahan keputihan sebanyak 101 siswi $(72,1 \%)$, selain itu mayoritas responden memperoleh sumber informasi tentang perilaku pencegahan keputihan melalui teman/keluarga yaitu sebanyak 65 siswi (46,4\%) [Tabel 2].

Siswi dengan perilaku pencegahan keputihan baik memiliki motivasi diri tinggi yaitu sebanyak 77 orang $(55,0 \%)$ dan untuk perilaku pencegahan keputihan buruk pada siswi yang memiliki motivasi diri rendah yaitu sebanyak 27 orang (19,3\%). Siswi dengan perilaku pencegahan keputihan baik memiliki motivasi rendah yaitu sebanyak 21 orang $(15,0 \%)$. Analisis hubungan dengan uji statistik regresi logistic ditemukan $\mathrm{p}=0,000$, artinya ada hubungan yang signifikan motivasi diri dengan perilaku pencegahan keputihan siswi di SMA Hang tuah 2 Sidoarjo. Nilai $\operatorname{Exp}$ (B): 9,786 yang artinya siswi yang memiliki motivasi diri tinggi 9, 786 kali berpengaruh melakukan perilaku pencegahan keputihan dengan baik [Tabel 3].

Siswi dengan perilaku pencegahan keputihan baik merasakan manfaat tinggi yaitu sebanyak 90 orang $(64,3 \%)$ dan untuk perilaku pencegahan keputihan buruk pada siswi yang merasakan manfaat rendah yaitu sebanyak 25 orang $(17,9 \%)$. Siswi dengan perilaku pencegahan keputihan baik merasakan manfaat rendah sebanyak 8 orang $(5,7 \%)$. Analisis hubungan dengan uji statistik regresi logistic 
ditemukan $\mathrm{p}=0,000$, artinya ada hubungan yang signifikan manfaat yang dirasakan dengan perilaku pencegahan keputihan siswi di SMA Hang tuah 2 Sidoarjo. Nilai Exp (B): 25,105 yang artinya siswi mersakan manfaat tinggi 25,105 kali berpengaruh melakukan perilaku pencegahan keputihan dengan baik.
Siswi dengan perilaku pencegahan keputihan baik memiliki komitmen tinggi yaitu sebanyak 80 orang $(57,1 \%)$ dan untuk perilaku pencegahan keputihan buruk pada siswi yang memiliki komitmen rendah yaitu sebanyak 17 orang $(12,1 \%)$. Siswi dengan perilaku pencegahan baik memiliki komitmen lemah sebanyak 18 orang $(12,9 \%)$. Analisis hubungan

Tabel 1. Karakteristik Demografi Responden ( $\mathrm{n}=140)$

\begin{tabular}{|c|c|c|}
\hline Karakteristik & $\mathbf{n}$ & $\%$ \\
\hline $\begin{array}{l}\text { Umur } \\
15 \text { tahun } \\
16 \text { tahun } \\
17 \text { tahun }\end{array}$ & $\begin{array}{c}4 \\
113 \\
23\end{array}$ & $\begin{array}{r}2,9 \\
80,7 \\
16,4\end{array}$ \\
\hline $\begin{array}{l}\text { Usia Menarch } \\
\quad<10 \text { tahun } \\
10-14 \text { tahun } \\
>14 \text { tahun }\end{array}$ & $\begin{array}{c}1 \\
137 \\
2\end{array}$ & $\begin{array}{c}0,7 \\
97,9 \\
1,4\end{array}$ \\
\hline $\begin{array}{l}\text { Saudara perempuan } \\
\text { Ya } \\
\text { Tidak }\end{array}$ & $\begin{array}{l}71 \\
69\end{array}$ & $\begin{array}{l}50,7 \\
49,3\end{array}$ \\
\hline $\begin{array}{l}\text { Tempat Tinggal } \\
\text { Rumah Ortu } \\
\text { Kos }\end{array}$ & $\begin{array}{c}140 \\
0\end{array}$ & $\begin{array}{c}100 \\
0\end{array}$ \\
\hline $\begin{array}{l}\text { Penghasilan Ortu } \\
\quad>3.5 \text { juta } \\
2,5 \text { juta- } 3,5 \text { juta } \\
1,5 \text { juta- } 2,5 \text { juta } \\
500 \text { ribu- } 1,5 \text { juta }\end{array}$ & $\begin{array}{c}83 \\
36 \\
14 \\
7\end{array}$ & $\begin{array}{c}59,3 \\
25,7 \\
10,0 \\
5,0\end{array}$ \\
\hline
\end{tabular}

Tabel 2. Karakteristik Responden Berdasarkan Informasi ( $\mathrm{n}=140)$

\begin{tabular}{lcc}
\hline Karakteristik & $\mathbf{n}$ & $\mathbf{\%}$ \\
\hline Tahu Keputihan & 118 \\
Ya & 22 & 84,3 \\
Tidak & 15,7 \\
Tahu Perilaku pencegahan keputihan & 101 \\
Ya & 39 \\
Tidak & 72,1 \\
Sumber Informasi & 27,9 \\
Teman/keluarga & 65 \\
Pelayanan Kesehatan & 7 & 46,4 \\
Buku/Leaflet & 2 & 5,0 \\
Internet/media sosial & 27 \\
Tidak Tahu & 27 & 19,3 \\
\hline
\end{tabular}

Siswi dengan perilaku pencegahan keputihan baik memiliki pengaruh interpersonal tinggi yaitu sebanyak 51 orang $(36,4 \%)$ dan untuk perilaku pencegahan keputihan buruk pada siswi yang memiliki pengaruh interpersonal rendah yaitu sebanyak 9 orang $(6,4 \%)$. Siswi dengan perilaku pencegahan baik memiliki pengaruh interpersonal rendah sebanyak 47 orang $(33,6 \%)$. Analisis hubungan dengan uji statistik regresi logistic ditemukan $\mathrm{p}=0,020$, artinya ada hubungan yang signifikan pengaruh interpersonal dengan perilaku pencegahan keputihan siswi di SMA Hang tuah 2 Sidoarjo. Nilai $\operatorname{Exp}(B):$ 0,256 yang artinya siswi yang memiliki pengaruh interpersonal tinggi 0,256 kali berpengaruh dalam melakukan perilaku pencegahan keputihan dengan baik. dengan uji statistik regresi logistic ditemukan $\mathrm{p}=0,102$, artinya tidak ada hubungan antara komitmen tindakan dengan perilaku pencegahan keputihan siswi di SMA Hang tuah 2 Sidoarjo.

\section{PEMBAHASAN}

4.1 Hubungan motivasi diri dengan perilaku pencegahan keputihan

Hasil penelitian variabel motivasi diri menunjukkan bahwa siswi yang memiliki motivasi diri tinggi akan melakukan perilaku pencegahan keputihan dengan baik. Hasil uji regresi logistik menunjukkan bahwa motivasi diri memiliki hubungan yang signifikan dengan perilaku pencegahan keputihan. Penelitian lain mengenai motivasi diri yang dilakukan oleh (17) juga menunjukkan hasil yang signifikan terhadap 
perilaku pencegahan gizi buruk pada balita. Menurut penelitian (18) tentang hubungan motivasi diri terhadap perilaku ibu dalam upaya pencegahan anemia juga menunjukkan hasil yang signifikan.

Teori health promotion model (5), menjelaskan bahwa faktor personal baik faktor biologis maupun psikologis (motivasi diri) akan memprediksi pemberian perilaku dan dibentuk secara alami dalam target perilaku menjadi pertimbangan. Motivasi adalah proses memberi semangat, arah, dan kegigihan perilaku. Artinya, perilaku yang termotivasi adalah perilaku yang penuh energi, terarah dan bertahan lama. Oleh karena itu konsep penting dari teori motivasi ini adalah pada kekuatan yang ada di dalam diri manusia, sehingga semakin kuat motivasi diri maka semakin baik perilaku seseorang. Motivasi diri sangat diperlukan bagi siswi dalam melakukan perilaku pencegahan keputihan. terkadang siswi akan mengalami kecemasan. Oleh karena itu dukungan sosial ibu menjadi faktor yang sangat kuat terhadap kecemasan remaja dalam menghadapi menstruasi (21). Faktor sosial ekonomi dan demografi mempengaruhi kesehatan reproduksi terutama kemiskinan, tingkat pendidikan yang rendah dan ketidaktahuan tentang perkembangan seksual dan proses reproduksi, serta lokasi tempat tinggal yang terpencil (22).

Faktor seperti sosial ekonomi keluarga adalah salah satunya. Dari data yang ada didapatkan orang tua siswi memiliki penghasilan yang baik sehingga siswi yang berasal dari keluarga yang mampu mungkin tidak menjadi masalah. Sebaliknya, bagi siswi yang berasal dari keluarga yang kurang mampu akan menjadi masalah. Sebagai contoh dalam perawatan kebersihan alat reproduksi, responden harus mengeluarkan biaya untuk membeli

Tabel 3. Faktor Perilaku Pencegahan Keputihan Berdasarkan Teori HPM: Motivasi Diri, Manfaat yang dirasakan, Pengaruh Interpersonal, dan Komitmen Tindakan $(n=140)$

\begin{tabular}{|c|c|c|c|c|c|c|c|c|}
\hline \multirow{3}{*}{ Variabel } & \multicolumn{4}{|c|}{$\begin{array}{c}\text { Perilaku Pencegahan } \\
\text { Keputihan }\end{array}$} & \multirow{2}{*}{\multicolumn{2}{|c|}{ Total }} & \multicolumn{2}{|c|}{ Regresi Logistik } \\
\hline & \multicolumn{2}{|c|}{ Buruk } & \multicolumn{2}{|c|}{ Baik } & & & & \\
\hline & $\mathbf{n}$ & $\%$ & $\mathbf{n}$ & $\%$ & $\Sigma$ & $\%$ & $(p)$ & $\operatorname{Exp}(B)$ \\
\hline \multicolumn{9}{|l|}{ Motivasi } \\
\hline Rendah & 27 & 19,3 & 21 & 15,0 & 48 & 34,3 & \multirow[t]{2}{*}{0,000} & \multirow[t]{2}{*}{9,786} \\
\hline Tinggi & 15 & 10,7 & 77 & 55,0 & 92 & 65,7 & & \\
\hline \multicolumn{9}{|c|}{ Manfaat yang dirasakan } \\
\hline Rendah & 25 & 17,9 & 8 & 5,7 & 33 & 23,6 & \multirow[t]{2}{*}{0,000} & \multirow[t]{2}{*}{25,105} \\
\hline Tinggi & 17 & 12,1 & 90 & 64,3 & 107 & 76,4 & & \\
\hline \multicolumn{9}{|c|}{ Pengaruh Interpersonal } \\
\hline Rendah & 9 & 6,4 & 47 & 33,6 & 56 & 40 & \multirow[t]{2}{*}{0,020} & \multirow[t]{2}{*}{0,256} \\
\hline Tinggi & 33 & 23,6 & 51 & 36,4 & 84 & 60 & & \\
\hline \multicolumn{9}{|c|}{ Komitmen tindakan } \\
\hline Lemah & 17 & 12,1 & 18 & 12,9 & 35 & 25 & \multirow[t]{2}{*}{0,102} & \multirow[t]{2}{*}{2,463} \\
\hline Kuat & 25 & 17,9 & 80 & 57,1 & 105 & 75 & & \\
\hline
\end{tabular}

Apabila terdapat motivasi diri pada siswi maka ada keinginan dari dalam diri siswi untuk melakukan perilaku pencegahan keputihan.

Selain faktor psikologis (motivasi diri) dapat mempengaruhi perilaku pencegahan keputihan, faktor biologis seperti usia, usia menarche, dan faktor sosial ekonomi juga dapat mempengaruhi perilaku pencegahan keputihan. Menurut (19) juga mengemukakan pendapatnya bahwa usia seseorang mempengaruhi kemampuan seseorang untuk menerima informasi dan pola pikir seseorang untuk menerima informasi yang diberikan. Rata-rata usia siswi yaitu 16 tahun yang termasuk remaja pertengahan yang perlu bimbingan untuk menuju remaja penuh menuju dewasa. Usia menarch juga dapat mempengaruhi perilaku pencegahan keputihan. Usia menarche siswi mayoritas 10-14 tahun dimana pada usia tersebut merupakan usia normal siswi mendapatkan menarche.

Menurut (20) menarche pada usia yang terlalu dini mengakibatkan siswi harus mengalami menstruasi yang lebih lama dibanding teman sebayanya dan harus menyesuaikan anatomi tubuh dan psikologinya yang mulai berubah sehingga perlengkapan seperti pembalut. Siswi yang berasal dari keluarga mampu akan melakukan penggantian pembalut dengan frekuensi yang lebih sering, namun berbeda halnya responden dari keluarga kurang mampu. Dengan keterbatasan biaya dalam membeli pembalut, responden akan mengganti pembalut apabila dirasa sudah waktu untuk mengganti. Menurut (23), menyatakan bahwa ketika haid intensitas penggantian pembalut lebih sering akan mencegah terjadinya keputihan.

\subsection{Hubungan manfaat yang dirasakan dengan} perilaku pencegahan keputihan

Manfaat yang dirasakan (perceived benefits) menunjukkan hubungan signifikan terhadap perilaku pencegahan keputihan. Penelitian lain oleh (24) yang dilakukan terhadap pasien tuberculosis tentang manfaat yang dirasakan (perceived benefits) juga menunjukkan hasil yang signifikan terhadap perilaku kesehatan. Siswi yang merasakan manfaat yang tinggi juga melakukan perilaku pencegahan keputihan dengan baik. Hal ini sesuai dengan teori health promotion model (5), dimana dalam teori tersebut menjelaskan bahwa manfaat yang dirasakan 
(perceived benefits to action) menjadi salah satu faktor yang mempengaruhi dari perilaku seseorang. Manfaat tindakan ini menjadi gambaran mental positif atau reinforcement positif bagi perilaku.

Manfaat dari penampilan perilaku tersebut dapat dirasakan baik secara intrinsik maupun ekstrinsik. Siswi yang merasakan manfaat tinggi akan melakukan perilaku pencegahan dengan baik. Siswi menyadari bahwa jika mereka mengetahui dan melakukan perilaku pencegahan dengan baik, maka semakin banyak pula manfaat yang dirasakan oleh siswi seperti terhindar dari keputihan, infeksi, penyakit radang panggul, dan infertilitas serta komplikasi lebih lanjut seperti tumor atau kanker. Penelitian (25) menjelaskan bahwa penyebab infeksi keputihan yang sering terjadi pada wanita diantaranya bakteri vaginosis, selain itu kandidiasis, trikomoniasis, juga menjadi penyebab terjadinya keputihan.

\subsection{Hubungan Pengaruh Interpersonal terhadap Perilaku Pencegahan Keputihan}

Pengaruh Interpersonal memiliki hubungan yang signifikan terhadap perilaku pencegahan keputihan. Menurut penelitian (24) juga menunjukkan bahwa ada hubungan yang signifikan antara pengaruh interpersonal dengan perilaku pencegahan tuberculosis. Penelitian lain yang dilakukan oleh (26) menunjukkan bahwa ada hubungan pengaruh interpersonal terhadap perilaku waspada stroke pada resiko tinggi. Dalam penelitian ini menunjukkan siswi yang mendapat pengaruh interpersonal tinggi akan melakukan perilaku pencegahan keputihan dengan baik. Penelitian yang sama juga menunjukkan bahwa dukungan keluarga dan teman sebaya menjadi faktor yang berpengaruh dalam perilaku pencegahan keputihan.

Menurut teori health promotion model (5), menjelaskan bahwa pengaruh interpersonal menjadi faktor yang mempengaruhi hasil akhir perilaku seseorang. Pengaruh interpersonal merupakan kognisi tentang perilaku, kepercayaan atau sikap orang lain. Sumber utama interpersonal adalah keluarga, individu/kelompok, dan pemberi pelayanan kesehatan. Dukungan keluarga atau teman sebaya sangat berpengaruh terhadap perilaku pencegahan keputihan. Ketika siswi mendapatkan dukungan dari orang terdekat seperti keluarga dan teman sebaya baik dukungan secara informatif, emosional, ataupun peran maka siswi akan melakukan perilaku pencegahan dengan baik pula. Dengan dukungan informatif yang didapatkan siswi akan mendapatkan tambahan pengetahuan dan ilmu baru dalam upaya pencegahan keputihan, dukungan secara emosional seperti memberikan pujian juga dapat menjadi semangat siswi untuk melakukan perilaku pencegahan keputihan.

Penelitian (19) mengungkapkan bahwa terdapat hubungan antara tingkat pengetahuan tentang keputihan dengan perilaku pencegahan pada remaja. Semakin baik pengetahuan remaja maka semakin baik pula perilaku pencegahan keputihan. Adanya hubungan antara pengetahuan dengan perilaku pencegahan keputihan pada siswi menunjukkan pentingnya informasi untuk meningkatkan pengetahuan agar berusaha sebaik mungkin dalam berperilaku mencegah timbulnya keputihan. Mayoritas sumber informasi yang didapatkan oleh siswi yaitu berasal dari keluarga atau teman. Sumber informasi mempengaruhi sikap remaja terhadap keputihan (27).

Seperti faktor personal, perilaku pencegahan keputihan juga dipengaruhi oleh tempat tinggal. Siswi harus menyesuaikan diri dengan lingkungan tempat tinggalnya dimana seharusnya orang tua dan saudara yang dapat menyakinkan dan dapat dipercaya oleh siswi dalam berperilaku pencegahan keputihan (7). Orang tua dan saudara dapat memberikan dukungan dalam bentuk informative, nilai, ataupun role model. Informasi yang diberikan yaitu pengetahuan mengenai kesehatan reproduksi salah satunya upaya pencegahan keputihan, kemudian untuk nilai yaitu keluarga dapat memberikan pujian ketika mereka berhasil melakukan perilaku pencegahan dengan baik sehingga diharapkan dengan pujian tersebut dapat memberikan semangat untuk melakukan perilaku pencegahan keputihan dengan baik lagi. Pengalaman yang telah dialami oleh orang tua atau sodara dapat menjadikan sosok role model bagi mereka untuk mencegah hal tersebut juga dialami oleh mereka.

Penelitian yang dilakukan (19) menyatakan bahwa pengetahuan mempengaruhi resiko terjadinya keputihan, sedangkan pengetahuan dan informasi yang bisa dipercayai adalah dari orang tua. Sehingga siswi yang tinggal dengan orang tua yang mendapatkan informasi dan perhatian lebih akan melakukan perilaku pencegahan keputihan dengan baik dibandingkan dengan siswi yang tinggal sendiri di kos. Hubungan antara orang tua dan anak serta kontrol perilaku orang tua akan mempengaruhi penghindaran resiko seksual baik secara langsung atau tidak langsung (28).

\subsection{Hubungan komitmen tindakan terhadap perilaku pencegahan keputihan}

Komitmen tindakan tidak memiliki hubungan yang signifikan terhadap perilaku pencegahan keputihan. Penelitian yang sama tentang komitmen tindakan namun terhadap perilaku pencegahan kusta oleh (16) juga menunjukkan hasil yang tidak signifikan. Namun ada beberapa penelitian mengenai komitmen tindakan terhadap perilaku pencegahan gizi buruk pada balita oleh (17) menunjukkan ada hubungan antara komitmen tindakan dengan perilaku pencegahan gizi buruk pada balita. Menurut teori health promotion model (5) yang menjelaskan bahwa komitmen tindakan merupakan salah satu faktor yang mempengaruhi perilaku seseorang.

Hal yang mendasari dari komitmen yaitu komitmen untuk melaksanakan tindakan spesifik sesuai waktu dan tempat dengan orang-orang tertentu atau sendiri, identifikasi strategi tertentu untuk mendapatkan, melaksanakan, atau penguatan 
terhadap perilaku. Hasil yang menunjukkan bahwa komitmen tindakan tidak memiliki hubungan kemungkinan karena komitmen sendiri dipengaruhi oleh beberapa faktor lain seperti hambatan tindakan, self efficacy, dan sikap dimana faktor-faktor tersebut menjadi pendukung dalam komitmen tindakan dan perilaku pencegahan keputihan. Salah satu contoh yaitu penggunaan celana jeans yang ketat dikalangan remaja merupakan sebuah trend fashion dan sering digunakan oleh remaja, padahal penggunaan celana yang terlalu ketat juga dapat menghambat aliran udara sehingga keringat sulit diserap dan bakteri mudah berkembang yang menyebabkan keputihan (11) Selain itu, berdasarkan hasil jawaban responden pada kuesioner komitmen tindakan pun juga menunjukkan bahwa siswi cenderung tidak mengggunakan pakaian dalam yang berbahan katun.

Hal tersebut dapat menjadi alasan siswi sulit berkomitmen untuk beralih menggunakan celana longgar dan memilih pakaian dalam yang mudah menyerap keringat seperti katun sebagai bentuk perilaku upaya pencegahan keputihan (29). Personal hygiene yang buruk pada area genetalia menyebabkan kuman, virus, dan parasit berkembang pesat di daerah sekitar genetalia (12). Oleh karena itu, diperlukan upaya untuk meningkatkan komitmen siswi dalam melakukan perilaku pencegahan keputihan dengan baik antara lain: perlunya edukasi yang dapat diberikan melalui penyuluhan kesehatan, perlu diadakannya kegiatan yang berhubungan dengan kesehatan reproduksi melalui kegiatan ekstrakurikuler atau konsultasi masalah kesehatan di UKS.

Perilaku pencegahan keputihan menjadi salah satu cara untuk meningkatkan kesehatan reproduksi remaja secara optimal. Perilaku pencegahan yang dilakukan siswi dengan baik dipengaruhi oleh berbagai faktor, baik berasal dari internal maupun eksternal. Kemampuan siswi untuk mempertahankan kondisi kesehatannya dengan keyakinan bahwa lebih baik melakukan pencegahan penyakit yang diharapkan dapat memberikan dampak positif bagi kesehatannya.

\section{KESIMPULAN}

Siswi yang berperilaku pencegahan keputihan baik memiliki motivasi diri, manfaat yang dirasakan (perceived benefits) dan pengaruh interpersonal yang tinggi. Siswi yang melakukan perilaku pencegahan keputihan tidak semua memiliki komitmen tindakan yang kuat karena komitmen sendiri dipengaruhi oleh beberapa faktor lain seperti hambatan tindakan, self efficacy, dan sikap dimana faktor-faktor tersebut menjadi pendukung dalam komitmen tindakan dan perilaku pencegahan keputihan bagi siswi. Oleh karena itu, diharapkan pada penelitian selanjutnya untuk menggunakan rentang waktu yang lebih lama yaitu kurang lebih satu minggu dan melakukan observasi kepada responden untuk mengetahui perkembangan perilaku kearah yang lebih positif.

\section{UCAPAN TERIMA KASIH}

Kami mengucapkan terima kasih kepada Kepala SMA Hang Tuah 2 Sidoarjo untuk izin dan penerimaan dalam proses pengambilan data sebagai bahan penelitian dan siswi kelas XI yang telah bersedia menjadi responden dalam penelitian ini.

\section{DAFTAR PUSTAKA}

1. Sarwono. Psikologi Remaja. Jakarta: PT. Raja Grafindo Persada; 2011.

2. Bobak IM, Jensen MD, Lowdermilk DL, Anugerah PI, Wijayarini MA. Buku Ajar Keperawatan Maternitas. 4th ed. Jakarta: EGC; 2012.

3. Sibagariang, Pusmaika. Kesehatan Reproduksi Wanita. Jakarta: Trans Info Media; 2010.

4. Abrori, D Hernawan A, Ermulyadi. Faktor yang Berhubungan dengan Kejadian Keputihan Patologis Siswi SMAN 1 Simpang Hilir Kabupaten Kayong Utara. Unnes J Public Heal. 2015;6(1):25-33.

5. Pender NJ. Health Promotion in Nursing Practice. 2015.

6. WHO. Reproductive, Maternal, Newborn, Child, Adolescent Health And Undernutrition. 2015.

7. Azizah N, Widiawati I. Karakteristik Remaja Putri dengan Kejadian Keputihan di SMK Muhammadiyah Kudus. J Ilm Kesehat. 2015;6(1):57-78.

8. BKKBN, BPS, Kemenkes. Survei Kesehatan Reproduksi Remaja Indonesia. Jakarta: BPS; 2009.

9. Sugiharti. Perilaku Berisiko Remaja di Indonesia Menurut Survei Kesehatan Reproduksi Remaja Indonesia (SKRRI) Tahun 2007. Kesehat Reproduksi. 2011;1(3):136-44.

10. Triyani R, Ardiani S. Hubungan pemakaian pembersih vagina dengan kejadian keputihan pada remaja putri. J Ilm Kebidanan. 2013;4(1):1-11.

11. Ali RFM. Hubungan frekuensi penggunaan celana ketat ( jeans ) dengan kejadian keputihan ( fluor albus ) pada mahasiswi fakultas ilmu kesehatan universitas muhammadiyah malang. 2011;

12. Indriyani $R$, Studi $P$, Kebidanan D, Indriyawati $Y$, Studi P, Kebidanan D, et al. Hubungan Personal Hygiene Dengan Kejadian Keputihan Pada Siswi Ma Al- Hikmah Aeng Deke Bluto. 2012;

13. Persia A, Gustia R, Bahar E. Hubungan Pemakaian Panty Liner dengan Kejadian Fluor Albus pada Siswi SMA di Kota Padang. J Kesehat Andalas. 2015;4(2):2.

14. Aldila MD. Analisis Faktor Yang Berhubungan Dengan Perilaku Pencegahan Keputihan Pada 
Remaja Berdasarkan Theory of Planned Behavior (TPB). Keperawatan. 2017;

15. Indrawati L. Analisis faktor yang berhubungan dengan kemampuan pasien melakukan pencegahan sekunder faktor risiko di RSPAD Gatot Soebroto Jakarta. 2012.

16. Prasdawati N. Pengaruh Faktor Interpersonal, Situasional, dan Komitmen Tindakan Keluarga Terhadap Perilaku Pencegahan Penularan Kusta. Keperawatan Unair. 2014;

17. Fauziah IN, Djuari L, Arief YS. Pengembangan model perilaku ibu dalam pencegahan gizi buruk balita. Ners. 2015;10(2):195-207.

18. Nurbadriyah WD. Perilaku ibu dalam pencegahan anemia anak prasekolah berbasis. Kesehat Hesti Wira Sakti. 2017;5(1):68-75.

19. Wantania J, Wagey F. Hubungan Tingkat Pengetahuan Tentang Keputihan. 2015;3(April):1-5.

20. Monalisa; Bubakar A dkk. Clinical Aspects Fluor Albus Of Female And Treatment. 2012;

21. Purwaningsih DA, Ketut N, Armini A, Nastiti AA. Lesson Learn Mothers Social Support Decrease. 2008;(031):1-7.

22. Johar WE, Rejeki S, Khayati N. Persepsi dan Upaya Pencegahan Keputihan pada Remaja Putri di SMA Muhammadiyah 1 Semarang. JKMat
(Jurnal Keperawatan Matern. 2013;1(1):37-45.

23. Odabas D. Original Study Personal Hygiene and Vulvovaginitis in Prepubertal Children. 2016;

24. Hidayat NZ. Hubungan Persepsi Dengan Perilaku Kesehatan Masyarakat Terhadap Penderita Tuberculosis Berbasis Health Promotion Model. Keperawatan. 2017;

25. Sivaranjini R, Jaisankar TJ, Thappa DM, Kumari $\mathrm{R}$, Chandrasekhar L, Malathi M, et al. Spectrum of vaginal discharge in a tertiary care setting. 2013;3(2):135-40.

26. Ambarika R, Agoes A, Kristianto H. Analisis Faktor yang Berhubungan dengan Perilaku Waspada Stroke pada Kelompok Resiko Tinggi. Indones J Heal Sci. 2015;5(2):223-42.

27. Sariyati S. Faktor-Faktor yang Mempengaruhi Sikap Remaja Putri tentang Flour Albus di SMP Negeri 2 Trucuk Kabupaten Klaten Factors That Affects Adolescent Girls Attitude about Flour Albus in Trucuk 2 Junior High Schools District Klaten. :117-21.

28. Keeler HJ. Mother Child Connectedness, Parental Behavioral Control, Psychosocial Maturity and Adolescent Sexual Health Risk Behavior. 2010;

29. Putri R, Smpn DI, Tangerang T, Ajeng A, Annisatya A. Imj: indonesian midwifery journal 35. :35-44. 